\title{
MODERN INTELLECTUAL APPROACHES TO ISLAMIC LAW
}

\author{
Ahmad Kazemi-Moussavi*
}

\begin{abstract}
This article deals with creative proposals by four contemporary authors who promoted reform either from within the sharī a $h$ or by borrowing methods such as empiricism and hermeneutics beyond the conventional scope of the sharī ah. To revive the forgotten sphere of Islamic public law, Mohammad Hashim Kamali puts forth the idea of identifying Islamic notions of ijmā', shūrā and ijtihād with modern statutory law and government ordinances. 'Abd al-Ḥamīd Abū Sulaymān proposes that the application of Islamic legal norms (ahkām) must be aligned within space-time considerations, which centre on two principles of necessity and fine-tuning (talfīq). Tāanā Jābir al- 'Alwānī signifies the important role that knowledge of 'rational priorities' ( 'ilm al-awlawiyyāt) can play in balancing and stabilising Islamic jurisprudence. He extends the scope of ijtihād in such broad sense to bring the higher objectives of the sharī ah into account to conform to timely requirements. Nașr Ḥāmid Abū Zayd is one of the first Muslim scholars to approach the sharī ah by applying modern hermeneutics as a method of inquiry into the interpretation of legal texts. The modern hermeneutics, he believes, opens the gate for new understandings to update Islamic law.
\end{abstract}

At the dawn of the twenty-first century, creative interpretations of the textual sources of Islamic law are the most salient feature of the current Islamic intellectual movement. Although overshadowed by political 'Islamism', the theoretical changes in contemporary Islamic legal thought appear to be the most compelling facet of the current intellectual revolution in the minds of modern Muslims. The rise to prominence of Islamic law in recent decades has ignited new approaches to the primary sources together with new methods of interpretation. At present, there are several quarters who voice a desire for an ideal application of Islamic legal norms

* Ahmad Kazemi-Moussavi is professor of Islamic law and Modern Iran in the University of Maryland at College Park MD, United States. This contribution is an extended version of an article by the same author which has appeared as "Modern Approaches to Islamic Law" in: Christoph Marcinkowski (ed.), The Islamic World and the West: Managing Religious and Cultural Identities in the Age of Globalisation (Freiburg Studies in Social Anthropology 24; Zurich: LIT Verlag, 2009), 263-88. 
as the central theme of their agenda. Under the umbrella of the shari' $a h$, some of them even defy the status quo to express a desire for social justice. In response, some Muslim scholars and intellectuals strive to rationalise this pressing aspiration with modern proposals and an updated presentation of the shari $a h$ that they find suitable for the requirements of the modern era.

The shari ' $a h$, as a blend of Islamic law, ethics, and rituals, does not have a unique entity, and it was often reshaped and presented in the form of fiqh (jurisprudence) echoing the dominant mindset of the time. However, modern scholars have introduced a new dimension to the interpretation of sources in which human rational concepts play a central role in discerning and defining the appropriate legal norms. By applying the methods of modern scholarship, some intellectuals propose an independent reading of the primary sources that run in fact contrary to conventional interpretations. Thus, we may discern two trends within modern Muslim scholarship:

1. those who promote reform from within the shari ${ }^{\prime}$ ah legal tradition, and

2. those who try to approach the shari' 'ah from the outside of the revealed law, that is to say, to apply the modern fields of linguistics and hermeneutics to the sharīah.

All of these approaches focus upon the method of reading the law from its original sources, i.e., ușull al-fiqh or Islamic legal methodology. This article surveys the proposals of four prominent figures who represent each trend by examining their methods of making Islamic law more relevant to the requirements of the modern era.

\section{Mohammad Hashim Kamali}

As an accomplished professor of Islamic law, Mohammad Hashim Kamali (b. 1944) combines an elaboration of the traditional legal methodology with proposals for adaptation to recent changes within Muslim societies. His consistent engagement with the law allowed him to not only produce detailed presentations of the various disciplines of the field, but also to come up with new proposals that may reconcile the legitimacy of Islamic law with the ruling Muslim governments. He has written several works on various branches of Islamic law, legal methodology, hadith studies, and human liberty in Islam. His two important contributions to the field, Principles of Islamic Jurisprudence and Sharī' ah Law: An Introduction, allow us to observe his ideas. In the 2003 edition of Principles of Islamic Jurisprudence, Kamali first recapitulates most topics of legal methodology, and then attempts to present a new

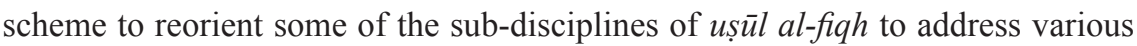
contemporary issues. 
In his introductory remarks, Kamali defines ușül al-fiqh as both 'methodology' and 'principles'. 'Methodology', in his view, concerns mainly methods of reasoning such as analogy (qiyās) and presumption of continuity (istișhāb), whereas 'principles' includes general directives that comprise the larger part of the primary sources that can be utilised as raw material in the development of law. Components of the methodology or principles are, however, identical and primarily include knowledge of the sources of the law and their order of priority, then legal rules, which may be deduced from the sources, and finally the exercise of ijtihäd. Kamali separates $i j t i h \bar{a} d$ from 'the deduction of rules' in order to give it an independent identity aimed at further adapting and refining in response to the changing needs of Muslim societies. ${ }^{1}$ In the second part of his introduction, Kamali distinguishes two main approaches to the study of ușül al-fiqh: theoretical and deductive. He states, "[w] hereas the former is primarily concerned with the exposition of theoretical doctrines, the latter is pragmatic in the sense that theory is formulated in light of its application to relevant issues". ${ }^{2}$ The arrangement of his ușül al-fiqh indicates that Kamali stands closer to the latter approach, as we will see below.

Kamali commences his account with the sources of the law, which are the Qur'ān and the sunnah. This marks his consideration for the theory of Islamic law that derives its legality from the fundamental sources of the law i.e. the Qur'ān and the sunnah. He later turns to the much elaborated yet complicated topic of 'legal language' or mabāhith al-alfāz. The topic of legal language is very important in Islamic law since it is considered not only a conduit for 'legal norms' ( $a h k \bar{a} m)$, but often the very ingredient of the legal norms. However, Kamali by separating 'literal indications' from 'textual implications' (dalālāt) draws a clear picture of what he rightly considers as 'Rules of Interpretation'. The former deals mainly with the proposition of words such as allegory ( $\left.m u^{\prime} a w w a l\right)$, metaphor (majāz), clear (wādihh) and unclear words; whereas the latter centres on textual implications such as alluded, inferred, or required meanings. Kamali allocates two chapters to the above topics under the rubric of 'Rules of Interpretation I' and 'Rules of Interpretation II' to distinguish the two sets of literal and contextual implications. ${ }^{3}$

The next chapter on legal language is entitled "Commands and Prohibitions" of the revealed texts. Kamali perceives this issue as a matter of the qur'ānic (and prophetic) language that follows up the discussion on the sources. ${ }^{4}$ Kamali characterises the Islamic conception of 'commands and prohibitions' as "often coupled with an appeal to the conscience of the individual", making it different from the 'imperative rules' of the modern laws that are often devoid of such appeal and confined to tangible results. ${ }^{5}$ This explains the importance of 'command and prohibitions' as the core issue of both Islamic legal language and legal norms.

In line with Kamali's elaboration on the revealed texts is the problem of 'abrogation' (naskh) that he then sets forth. Not content with depicting the opinions 
of the traditional authors like Ibn Salāmah alone, he reflects contemporary views of Wahbah al-Zuhaylī (b. 1932) and Abū Sulaymān and eventually concludes that "[n]askh is basically factual and has little juridical substance of its own, nor does it seem to have a direct bearing on the substance of legal theory" . ${ }^{6}$ For the same reason, one can transfer the topic of naskh from the adillah (indicants) to the 'conflict of evidences', a secondary issue discussed at the end of Kamali's work.

Kamali then turns to two other sources of Islamic law, ijma $\bar{a}^{\prime}$ and qiyās, on which he elaborates both the traditional and contemporary viewpoints at length. Afterwards, he brings to the fore two other methodologically trivial topics, namely 'revealed laws preceding the sharī 'ah of Islam' and 'the fatwā of a Companion'. Concerning the former, Kamali, on the authority of Abū Zahrah, concludes that "[...] disagreement among jurists on the authority or otherwise of the previous revelations is of little practical consequence, as the shari 'ah of Islam is generally self-contained and its laws are clearly identified". ${ }^{7}$ Regarding the latter, he draws attention to the fatwa of a companion which he feels either fits into the category of ijtihād or is provided to be a persuasive source of guidance having priority over the ijtihād of other mujtahids that may squeeze into the context of legal norms.

After covering revealed indicants, there remain a number of supplementary indicants that can simply be arranged under the rubric of 'rational indicants' (adillah al-'aqliyyah) as some Muslim uṣull authors did. They include istiḥsān (equity in Islamic law), al-mașālih al mursalah (considerations of public interest), istiṣhāb (presumption of continuity) and sadd al-dharā' $i$ ' (lit. 'blocking the means'). Kamali, however, follows the general pattern set by earlier Muslim authors, and deals with each of the above-mentioned topics as an independent subject matter. With reference to Islamic jurisprudence, Kamali propounds that the main object of analysing the textual sources and legal indicants is to arrive at a legal norm (hukm

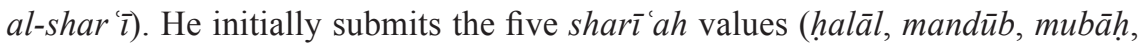
makrūh and harām), then the three legal sanctions (șậhh, fāsid and bätil) and lastly, the pillars of legal norm, i.e. the subject matter (referred to as mahkūm fih) and the authority of lawgiver (hākim), who must be capable of understanding the legal norm (mahkūm 'alayh). This pattern of hukm analysis that was proposed by al-Ghazālī and elaborated by al-Shawkānī and Abū Zahrah reiterates the status of legal norm from an individual perspective.

Kamali completes his arrangement of $u s \bar{u} l$ contents with the three essential topics of ' $u r f$, conflict of evidences, and $i j t i h \bar{a} d$, each of which he characterises as deserving an independent category. 'Urf is an important social concept and practice that can supplement the legal sources theoretically and practically. The theoretical role of ' $u r f$ can be seen in the principle of presumption of continuity (istiṣha a b) which originates from the normal practice of the people. The next subject, conflict of evidences, encompasses several juridical issues to which the $u s \underline{u} l$ methodology partly owes 
its origin. In the early stages, the argument on the conflicting authority of the legal sources - especially problems of abrogation and particularisation (takhșiṣ) - gave birth to uṣūl al-fiqh. For his last topic, Kamali not only elaborates on the procedure, variety, and qualification of ijtihād, but also presents an interesting account on how statutory legislation leaves a discouraging effect on the practice of ijtihād today. He concludes his remarks by referring to Muḥammad Iqbāl's (d. 1938) proposal for revitalising ijtihād by instituting an assembly of scholars practising ijma $\bar{a}^{\prime}$ (consensus) as part of the fabric of modern governments. ${ }^{8}$

Kamali's conception of collective ijtihād is much broader than the prevailing conventional understanding of the issue. Following Imām al-Shāfi '̄'s concept of the infallibility of general consensus of the Muslim community at large ('ámmatuhum là tajtama 'u 'alā khațā'), ${ }^{9}$ Kamali assigns legal authority to the collective ijtihād of Muslims either in the form shürā or $i j m \bar{a} '$. He criticises the traditional scholars who increasingly subjected the issue to difficult technical conditions to the point that $i j m \bar{a}$ ' altogether lost its popularity. To him, the qur'ānic verses on shūrā are inspiring enough to be translated into their own workable formula. ${ }^{10}$

In the last chapter of Principles of Islamic Jurisprudence, Kamali presents a new scheme for ușül al-fiqh that explores novel avenues for the utility and relevance of the discipline to today's statutory legislation. Like al-'Alwān̄̄ and Abū Sulaymān, Kamali's point of departure here is historical, as he sees a gap created between Muslim governments and the 'ulamā' by the historical isolation of Islamic legal scholarship (particularly Islamic legal methodology) from the state authority of respective governments. This approach signals the beginning of the struggle of Muslims to reduce the existing tension between theory and practice in Islamic thought. We shall see below how Kamali entertains new ideas to bridge the gap between government and legal scholarship. The second point of view is the time-space consideration that the traditional scholars often dispensed with. In his A New Scheme for Ușūl al-Fiqh, Kamali blames taqlīd (literalist approaches) and dogmatic interpretations for ignoring the role of time and space in the understanding of the Qur'ān and sunnah. In his paper “Toward a Maqāṣid-Oriented Legal Theory”, he re-introduces al-Shātibī's idea of considering the end-goals (maqāșid) of the sharī' $a h$ in relation to public and civic interests as a possible method of connecting these elements of time and space into the contemporary jurisprudence. ${ }^{11}$

Finally, Kamali presents his evaluation of the attempt of a contemporary Egyptian author, Jamāl al-Dīn 'Ațiyyah, to strike a balance between the need for continuity and preservation of Islamic values, and a purposeful move to change the existing impasse regarding ușūl al-fiqh. Kamali sees two Islamic core values, the qur'ānic notions of consultation (shürā) and the obedience to those who are in charge of community affairs (ulū 'l-amr), as having been neglected and therefore not fully integrated into the principles of Islamic jurisprudence or uṣul al-fiqh. He expects 
that governing authorities would extend their reach to the theoretical consensus, and even place their decisions on the same level as transmitted proofs. ${ }^{12}$ Relying on the above premises, Kamali supports the first three out of the following five of 'Ațiyyah's suggestions for a new division of the sources of the sharī'ah:

1. the transmitted proofs, which include the Qur'ān, sunnah and revealed laws preceding the shari 'ah of Islam;

2. ordinances of the ulu al-amr, which include $i j m \bar{a}{ }^{\prime}$ and $i j t i h \bar{a} d$;

3. the existing conditions or status quo, insofar as it is harmonious with the preceding two categories, and this includes custom ( $u r f$ ) and the presumption of continuity (istişhāb);

4. rationality ( $a q l$ ) in areas where full juridical ijtihād may not be necessary (the day-to-day rulings of government departments, for example, that seek to ensure good management of affairs may be based on rationality alone);

5. original absence of liability (barā'at al-așliyyah), which presumes permissibility and freedom from liability as the basic norm of the shari ${ }^{-} a h$ in respect of things, acts and transactions that have not been expressly prohibited. ${ }^{13}$

The significance of the above-mentioned suggestions essentially rests in the way they contribute to the legitimacy of a government of which most Muslim states are in a pressing need today. It is noteworthy that attempts to include ordinances of a Muslim government into the legal structure of the shari ${ }^{-} a h$ have precedence in Islamic scholarship. Some scholars have proposed the context of siyāsah shar 'iyyah (Islamic legal policy) that can overrule the textually derived rules of the shari $a h$, but they lack the universal value and durability required to preserve the tradition.

In his conclusion, Kamali once more attempts to bring the existing instruments of legal methodology into the service of today's social realities, that is, to merge 'the government ordinances' into ijtihād and 'statutory laws' into $i j m \bar{a} \cdot{ }^{\prime}{ }^{14}$ In this respect the government and the Muslim legislative assembly are entrusted with the role of being the main repository of ijtihād and ijm $\bar{a}$, and this move per se is considered to be in the direction of maqāșid. The conventional scope of maqāșid identified under five or six headings is evidently not enough and should be revised and supplemented in conformity with recent developments and the demands of contemporary life. ${ }^{15}$ As such, one can see that most of the proposed pretexts aim to bestow more legitimacy upon government ordinances. This seems to be a sound proposal as long as it is coordinated with the principles of 'checks and balances' that are mostly lacking in Muslim societies. In contrast, one may also expect to see that the maxim of the 'supremacy of the shari 'ah', one of the first principles of $u s \underline{u} l$ al-fiqh, to develop in such a manner as to guarantee the restrained nature of governmental authority. 
Kamali considers that the two important notions of $i j m \bar{a}$ ' and shürā have historically exhausted their traditional importance due to the lack of interest by Muslim scholars over time. In Islam, public participation is encouraged in both performing rituals and fulfilling social duties. The latter, nevertheless, has not received so much attention of the 'ulamà' as the former did. As a result, the rules of congregational prayers, for example, are far more elaborate than the principles of shüra that should shape the consultative part of Islamic government. Kamali's suggestion, therefore, offers a new outlook for reviving the forgotten sphere of Islamic public law.

\section{'Abd al-Ḥamīd Abū Sulaymān}

'Abd al-Hamīd Abū Sulaymān (b. 1936) is amongst those authors who sought to reform Islamic legal methodology from within the shari' 'ah and align the method of understanding it in relation to contemporary requirements. His approach to the sharī $^{\prime} a h$ is imbued with an assumed crisis in the minds of Muslims that prevented them from appreciating Islamic values in the light of time-space factors. While he has not written a work on Islamic legal or theoretical methodology, he has presented a broad criticism of traditional methodologies in which he re-evaluated the sources of the law and the method of juridical interpretation with reference to the international relations of Muslim governments.

Abū Sulaymān defines his approach to the sharī'ah as așālah or 'innovative', in contrast to some traditional approaches which he labels as 'imitative'. ${ }^{16}$ This approach reveals itself in his treatment of the authority of the sources of Islamic law; although, Abū Sulaymān adds many qualifications to bring his approach into line with the orthodox perception of the $\operatorname{sharī~}^{\prime} a h$. He divides the sources into two types: primary sources - including the Qur'ān, sunnah, consensus and qiyās - and secondary sources such as juridical preference (istihsānn), consideration of public interest, and obstruction of ostensibly legitimate means (sadd al-dharāyi $\left.{ }^{~}\right){ }^{17}$ Concerning the authority and application of the primary sources, Abū Sulaymān makes the following novel observations.

The Qur'ān, according to Abū Sulaymān, is the first revealed source of the Islamic law, and as such, should neither be considered a subject for abrogation, nor should it be divided into Meccan or Medinan verses. Rather, it should be regarded as part of the same whole, whose application must be aligned within space-time considerations, which are said to be applied "[...] in the light of changing circumstances in the overall flow of human life and experience". ${ }^{18}$ In this way he implies that this broader context can affect the basic principles of religion. Aware of possible problems, Abū Sulaymān tries to filter his idea through the conduit of ușūl al-fiqh. He ultimately reduces the problem of the space-time consideration into the application 
of two principles of darürah (necessity) and talfiq (lit. 'piecing together'). In this connection, he reconfirms the precedent of some Muslim muftis such as Rashīd Riḍā (d. 1935) who legitimised the charging of interest in today's banking system. ${ }^{19}$ In this case, Abū Sulaymān speaks about the necessity of methodological reforms, but elaborates only on the possible changes concerning the rules of abrogation.

The problem of conflict of laws was the raison d'être for the formation of ușūl al-fiqh. Muslim scholars have attempted to solve the problem firstly by delineating hierarchical considerations for the sources of the law, and secondly by setting rules for cases of abrogation (naskh) and particularisation (takhșiș), followed by semantic interpretations. According to Abū Sulaymān, Muslim scholars did not elaborate the philosophy of abrogation well enough to justify the flexibility of the law embedded within the Islamic legal system. He observes that:

The concept of naskh, as traditionally elaborated, reflects a static understanding in the methodology of Islamic thought, for it acts without taking notice of the difference between the general and universalistic nature of the qur'annic teachings as opposed to the specific and particularized treatment of subjects found in the sunnah. The traditional concept of naskh also reflects a total lack of appreciation for the elements of time and place in the process of interpreting and applying texts, as well as in comparing and analyzing them. ${ }^{20}$

By emphasising the late Medinan verses and traditions as a standard for Islam, Abū Sulaymān describes the prevalent juristic legal methodology as static, as it leaves aside many Meccan and the early Medinan verses and experiences. For instance, the universal verse of the early Medinan period "Let there be no compulsion in religion: Truth stands out clear from error" (2:256) was subverted by the late Medinan verse: "When the forbidden months are past, fight and slay the pagans wherever you find them" (9:5). According to Ibn Salāmah (d. 1019), this verse alone abrogated 124 earlier verses. ${ }^{21} \mathrm{Abu}$ Sulaymān observes that this genre of methodology suited the powerful governments of Umayyad and the early Abbasids during which Muslim jurisconsults standardised their methodologies. Contemporary Muslim jurists, though they have attempted to reinterpret many cases of naskh, seem to accept the same concept as permanent. Abū Sulaymān suggests that a way to solve this problem is "to reconcile verses that seemed to contradict one another in the light of space-time factors". ${ }^{22}$ This suggestion was in reality practised by Muslim societies of the past in the context of darürah and mașlahah. By considering both space and time, Abū Sulaymān nevertheless outlines a formula that is adaptable to the ever-changing situations within contemporary society.

Secondly, it is Abū Sulaymān's view that the traditions of the Prophet, more than the Qur'ān, reflect this space-time element; meaning, they should be read within their own context. While appreciating al-Shāfi 'î's effort to establish the authority of the sunnah, Abū Sulaymān nevertheless rejects the validity for today 
of al-Shāfi 'ì's view of the Prophet's attacks on the mushrikūn (the pagan Arabs) at least once a year. ${ }^{23}$ Instead, he determines that the prophetic traditions regarding war are not fully applicable to modern warfare. ${ }^{24} \mathrm{Abu}$ Sulaymān also criticises the historical arrangement of the traditions and finds it amazing that despite the usage of highly technical terminology in their categorisation, the traditions nevertheless appear somewhat disorganised and even inauthentic. This often engenders automatic criticism whenever an author cites a hadìth that serves little more than to distract readers from the point the author was trying to make..$^{25}$

Finally, the principle of Muslim consensus or ijm $\bar{a}$ ' is useless, according to Abū Sulaymān, unless new intellectual approaches to the traditional methodologies are developed. Basing $i j m \bar{a}^{\prime}$ on the agreement of mujtahids, who merely cite the authoritative ' 'ulam $\bar{a}$ ' in turn, only serves to add to the confusion. Today, different subjects require the consensus of experts drawn from many segments of society. By approaching these problems in this way, Abū Sulaymān develops formulas for the application of other disciplines such as empiricism and systematisation to jurisprudence. ${ }^{26}$

Abū Sulaymān considers qiyās, or juristic analogy, as a product of historical developments in the eighth century that aimed at supporting and maintaining the basic model of the early caliphate. As a supplement to qiyass, the principles of mașlahah and siyāsah shar iyyah (Islamic legal policy) were elaborated upon by later jurisconsults in response to the political conditions of the time. ${ }^{27}$ Abū Sulaymān does not assign any religious or rational value to these principles; rather, within his space-time theory, he is content with a historical analysis.

In the chapter "Reform of Methodology" in his Towards an Islamic Theory of International Relations, Abū Sulaymān advocates a new reading of the Qur'ān and sunnah. In his critical reading of Islamic history, he makes a number of interesting observations that may help us to understand the present state of stagnation within Muslim thought. He finds a series of undue rifts not only between religious and political leadership, but also between religious and empirical sciences. ${ }^{28} \mathrm{He}$ considers the replacement of caliphate with hereditary kingship as the main cause of the rift between governments and Muslim legal interpretation and their resulting scholarship. In his view, this rift not only led up to the isolation of the Islamic world, but is also 'the underlying cause of all the maladies that would later beset the ummah' ${ }^{29}$ The lack of empiricism within the religious sciences resulted in a disorientation of the latter from the time-space dimension that is necessary for updating these legal norms.

\section{Ṭāhā Jābir al-'Alwānī}

Among the graduates of the traditional school of Al-Azhar in Cairo, Ṭāhā Jābir al- 'Alwānī (b. 1935 in Iraq) is renowned for his time-honoured ideas, command 
of the sharì 'ah, and his legal methodology. He edited and published al-Mahșūul, the great $u s \underline{u} l$-work of Imam Fakhr al-Dīn al-Rāzī (d. 1209). This work pioneered al- 'Alwānī's legal outlook as depicted in several treatises and articles which he later wrote on legal methodology and the history and principles of Islamic jurisprudence. Al- 'Alwānī taught Islamic jurisprudence in Saudi Arabia for ten years before becoming a founding member and subsequently president of the International Institute of Islamic Thought (IIIT) in 1985. Currently, he is the president of Corboda University at Ashburn, Virginia, in the United States, where he holds the Imam al-Shāfi ' $\overline{1}$ Chair in Islamic Legal Theory. He has also written at length on the ethics of disagreement in Islam, appraisal of $i j t i h \bar{a} d$, and Islamisation of knowledge. Within the contexts of legal methodology and particularly ijtiha $\bar{d}$, as we will see below, al- 'Alwānī offers new proposals for the social problems facing today's Muslim societies.

Al- 'Alwānī holds the decline of ijtihād as the main cause of the present crisis of Islamic law. In several treatises, he surveyed the history of $i j t i h \bar{a} d$ and the rise of taqlìd (unquestioning following of the opinion and practice of others), and concludes that the present crisis of Islamic jurisprudence $(f i q h)$ started with the prevalence of the idea of a "closure of the door of ijtiha $\bar{a} d$ in the tenth century' ${ }^{30}$ He even marks the year 922, the date of demise of the historian and jurisprudent al-Țabarī, supposedly the last mujtahid, as the beginning of the crisis - 'the closing of the door of ijtihäd'. This phrase came practically to mean an official banning of public recognition for the existence or appearance of any new mujtahid. As a result, al- 'Alwānī argues, Islamic law was confined to the following of the opinions of one of the four early 'orthodox' Imams (Abū Ḥanīfah, Mālik, al-Shāfi ī and Ibn Ḥanbal).

It was for this reason that Imām al-Haramayn [d. 1086] claimed that there was ijmā [consensus] among the scholars of his day that taqlïd of one of the șahāabah [the Companions of the Prophet] was not acceptable. Rather, people were to adhere to the figh of the four imams who had probed and examined the shari ah, who had classified and given form to questions of figh, and who had digested the teaching and opinions of the Companions and the Successors. ${ }^{31}$

The circulation of such supposed consensus on banning the ijtiha $\bar{d}$ in the juristic circle of the thirteenth century led Ibn al-Șalah al-Shahrazūrī (d. 1245) to claim that "following one of the four Imams was obligatory (wäjib), as only their teaching had been systematised, clarified, and preserved". ${ }^{32}$ Ijtihäd as an intellectual exercise could not come to a complete halt, but, as a result of the above tacit consensus, it acquired an oblique path built on several temporary, rather miscellaneous formulas. For example, the hiyal wa 'l-makhärij, as well as legal stratagems and dodges, were proposed by traditional scholars to make an outlet for day-to-day problems facing Muslim societies. Al- 'Alwānī refutes this kind of marginal and superfluous solution, 
which often skirts the issue without setting a norm to deal with the core problem. ${ }^{33}$ His own proposals have so far been presented in two categories:

1. In his earlier works, al- 'Alwānī focused on the critical presentation of the history of Islamic jurisprudence and the methodology of $i j t i h \bar{a} d$, most of which may be considered as traditionally oriented proposals. In 1990, al- 'Alwānī published a treatise on the nature and history of the development of Islamic legal methodology (ușül al-fiqh), characterising it as "the most important method of research ever devised by Islamic thought" ${ }^{34}$ His evaluation of the nature and place of legal methodology centres on the history of the development and the role that ușūl al-figh played in conforming revelation with reason. He lays emphasis on the period of the Companions of the Prophet who are the source of the prophetic instructions after the Qur'ān. His main topic, however, consists of issues related to $i j t i h \bar{a} d$. To restore the practice of $i j t i h \bar{a} d$ in its proper sense, he proposes that:

(a) special attention should be paid to the methods of exercising ijtihäd by traditional scholars who developed theories for qiyās (legal analogy), istiḥsān (juristic preference) and mașlaḥah (consideration of public interests);

(b) since it is impossible to have an absolutely all-inclusive mujtahid, it is necessary to form a scholarly council, which should include experts specialising in all aspects of life;

(c) it is necessary to take an interest in knowing the purpose and end-goals of the shari ' $a h$ and setting guidelines to organise the study of problems. ${ }^{35}$

2. More updated ideas of al- 'Alwānī appear in his works on ijtihād and maqāșid. In an article published in 1991, al- 'Alwānī proposed that the dynamism of ijtihād should be used in restructuring an Islamic methodology ( $a l-m i n h \bar{a} j$ ) suitable for Islamisation of contemporary knowledge. He insisted that to construct such a methodology, it would be next to impossible to free oneself from the influence of Western scholarship; their categorisation and concepts. For this reason, he does not sketch a structure for such methodology other than notifying the need for definition, perspective and proper point of departure.$^{36}$ In a panoramic assessment of the progression of ijtihād, al- 'Alwānī divides methodological (ușūl) studies into two general categories of specialised and unspecialised studies.

The specialised studies match up more or less with the above-mentioned traditional approach of al- 'Alwānī. The unspecialised studies may also be subdivided into two categories: secular and non-secular. The former, according to al- 'Alwānī, are those who stretched the meaning of ijtihäd "to the breaking point to justify their dream of modernization and Westernization". ${ }^{37}$ For the latter groups, he offers the following remarks that should be attended before approaching a methodology: 
1. knowledge of the historical background to ijtihäd and taqlïd is necessary to understand the issues related to issues such as the division between intellectual (mainly juridical) and political authority in Islam;

2. the connection between ijtihād and the higher objectives (maquassid) of the shari ${ }^{\prime} a h$ is important to illustrate the affinity between ijtihād, or the antipathy between taqlìd and the maqāssid;

3. minute attention is required to the realization of multiplicity in ijtihād and to clarify the truth behind differences of opinion (ikhtiläf); and finally

4. the element of continuous self-renewal should be preserved through meeting and adjusting to changing circumstances. Ijtihād should not be considered a purely legalistic and legislative function. ${ }^{38}$

The above outline points only to the positive side of al- 'Alwānī's proposals. He does not fail, however, to equip his arguments with numerous mistakes and shortcomings performed by Muslims in exhorting ijtihäd especially during the recent history. By aiming to make Islamic legal methodology (ușül al-fiqh) relevant to today's problems, he does not find any avenue better than ijtihād in such broad sense to bring the higher objectives (maqāssid) of the shari' ah into account to conform to timely requirements. There is no need to emphasise that al- 'Alwānī wishes to see all changes within the limits of the shari 'ah rules and Islamic spirit.

Al- 'Alwān̄̄'s continuous search for dealing with questions facing Muslims today, but from an appropriately Islamic perspective, led him to another juridical formula, i.e. the 'knowledge of priorities' ( 'ilm al-awlawiyyāt). In a work published under the rubric of maqāssid al-sharī 'ah (The End-Goals of the sharì ah), al- 'Alwānī signifies the important role that knowledge of 'rational priorities' can play in balancing and stabilising Islamic jurisprudence. He justifies this fact with examples taken from topics of 'conflict of laws' (ta' $\bar{a} r u d$ ) and preferences (tarajīh) that originally stem from reason rather than revelation. What he interprets as awlawiyyāt in this context is much broader than the literal definition. A comprehensive knowledge of the shari ${ }^{\circ} a h$, i.e. Islamic theology as well as jurisprudence, is needed to acquire the wisdom of 'priorities'. ${ }^{39}$

The negative effects that result from disregarding the 'priorities' constitute a topic in which al- 'Alwānī elaborated on five unwanted outcomes. The first outcome is that Muslims have plunged into details [of the shari ${ }^{\prime} a h$ ] to the extent they are not able to systematise them, and to address the subtle relation between cases and principles. The second is the fact that they preferred to adhere to blind following (taqlīd) rather than carrying out their initiatives $(i j t i h \bar{a} d)$. Third, they placed too much significance upon supererogatory or optional undertakings, before obligatory actions. Fourth, Muslim jurists often rely upon their presumptions, and decline to find out the causality of things and to seek the relationship between cause and effect. 
Fifth, the overreliance upon the names of iconic (and often deceased) scholars from whom Muslims expect to hear the truth instead of verifying the authenticity of what they said. This is in fact a kind of idolatry (sanamiyyah) that deters Muslims from thorough contemplation. In the rest of his elaboration, al- 'Alwānī signifies how trivial trends of thought and superfluous spiritual displays occupied the minds of Muslims without making a real contribution to religion and society. ${ }^{40}$

The above outline points to remarkable focuses and explanations that al- 'Alwānī made on the principles of awlawiyyāt although their origins go back to al-Ghazālī's formula of munāsabah (lit. 'relevancy') and al-Shātibī's theory of maqāșid. In the later part of his book Maquașid al-sharī'ah, al- 'Alwānī acknowledges al-Ghazālī and especially al-Shātibī as precursors of the idea. Priorities which were not followed up by Muslims since the trivial notions kept them away from a proper course of dealing with the substantial problems. ${ }^{41}$ Al- Alwānī does not hesitate to point out the fact that his concept of priorities should indeed be understood along with the high purpose (maquassid) and command of the shari ${ }^{-} a h$ as the title of his book suggests.

Al- 'Alwānī is one of only a few Muslim authors who in their writings have presented scholarly opinions of Islamic thinkers regardless of their sectarian or devotional attachments. He refers to and sometimes incorporates the Shi' ite-oriented works of thinkers such as Sayyid Jamāl al-Dīn Afghānī (d. 1897) and Muhammad Husayn Nā'īnī (d. 1936) as much as he refers to their Sunni counterparts such as Shaykh Muḥammad 'Abduh (d. 1906) and 'Abd al-Raḥmān al-Kawākibī (d. 1902). ${ }^{42}$ Due to his pioneering work in The Ethics of Disagreement in Islam, al- 'Alwānī is well aware that he should not expect all Muslims, regardless of their circumstances and background, to realise the ideal vision of Islam. ${ }^{43}$ In this book, al- 'Alwānī finds examples of more tolerant and open-minded attitudes towards the disagreements of Islamic history, particularly from the precedents set by the Companions of the Prophet.

We now turn to the topic of new hermeneutical proposals for legal language in Islam. Ever since 1980, Islamic law not only adopted new ideas, but also became subject to an epistemological analysis, i.e. hermeneutics, a modern discipline concerned with the nature and presuppositions of the interpretation of religious texts. ${ }^{44}$ Before the 1980 s, most changes to the Islamic law were offered through the channels of interpretive disciplines such as $t a f s \bar{r} r$ (exegesis), ta' wìl (allegorical interpretation) and ijtihād (independent judgment) all enclosed by the rules of Islamic legal methodology. None of these devices were used to extend the meaning of a text beyond the intention of the lawgiver, nor beyond the religious context in which the text evolved. In contrast, modern approaches to the shari 'ah incorporate epistemology that can easily go beyond these primary textual sources. Innovative approaches to the sharì $a h$ are best reflected in the works and ideas of Abū Zayd. 


\section{Nașr Ḥāmid Abū Zayd}

The contemporary Egyptian author Nașr Ḥāmid Abū Zayd (b. 1943) is among the first Islamic scholars to approach the shari $a h$ by applying hermeneutics as a method of inquiry into the interpretation of legal texts. The early works of Abu Zayd centred on evaluating Islamic methods of semantics and its implications on the interpretation of the text, preceded by a brief survey in the theories of the European founders of hermeneutics such as Friedrich Schleiermacher (d. 1834) and Wilhelm Dilthey (d. 1911). He examined the writings of Mu'tazilite and Ash'arite scholars and grammarians such as al-Jāhịiz (d. 869) and al-Bāqillānī (d. 1012) in the light of theories of hermeneutics. ${ }^{45} \mathrm{Abu}$ Zayd presented a new, critical reading of the above-mentioned Muslim authors.

The controversial work of Abū Zayd is Mafhūm al-naș (The Concept of Text), a version of his discourses on the qur'ānic sciences. In this book, he launches a new way of reading the religious texts in the light of modern hermeneutics. To signify the importance of the 'text', Abū Zayd defines Arabian Islamic civilisation as a 'Civilization of the Text' (hadārat al-nașs) in contrast to Greek civilisation, which he dubs a 'Civilization of Reason' (hadārat al- 'aql). He emphasises an understanding of the texts that requires interpretative skills to discern the cultural context surrounding it. As the Qur'ān is the primary textual source of Islam, in categorising the verses, Abū Zayd prefers to characterise the verses revealed before the hijrah as 'faith-building', in contrast to those from after the hijrah (622/632) which are more concerned with 'building societal character' ${ }^{46}$ Nevertheless, the textual output of the Qur'ān was, in Abū Zayd's view, overshadowed by the immense sanctity later attached to it as the Holy Book. ${ }^{47}$

In one of his later works, Naqd al-khițāb al-dīn̄ (A Critique of Religious Discourse), Abū Zayd notes the abuse of the Qur'ān by Mu'āwiyah (d. 680), the founder of the Umayyad dynasty who placed leaves of the Qur'ān on lances in an attempt to divert Muslims' attention from their own ijtihād to an expected direct judgment of the Qur'ān. "The Qur'ān is just pieces of writing", Abū Zayd quotes the fourth caliph 'Alī b. Abī Ṭālib (d. 661) saying in the War of Șiffīn, "[i]]t [i.e. the Qur'ān] does not speak; only men speak for it". Abū Zayd concludes that the texts require a certain scope of rational interpretation that only the human mind can afford. ${ }^{48}$

Abū Zayd claims that the understanding of a text revolves around the data and perceptions of the time of the reader. He quotes from Literary Identity, written by the contemporary author Peter W. Nesselroth who argues that the process of understanding a text does not begin with reading the text, but rather it starts prior to that with the dialogue between the culture shaping the reader's perception and the text. In the case of the Qur'ān, knowledge of the 'occasions of revelation' is 
necessary for eliciting a legal norm $(h u \mathrm{~km})$ or for inferring a meaning of one. But Muslim interpreters often assumed an independent entity for the qur'ānic legal norms by separating the text from the legal norm $(\mathrm{hukm})$. Some of them even claimed that the $h u k m$, or the command of God existed before the revelation and appearance of the text. ${ }^{49} \mathrm{Abu}$ Zayd draws out three factors that may cause this misunderstanding:

1. The literal implication (al-dalälah al-lughawiyyah) was confused by some interpreters with the legal implication (al-dalälah al-shar iyyah), as in the qur'ānic verse 87:14: "But those will prosper who purify themselves". 'Purification' in this Meccan verse does not imply zakāh (legal alms) which, according to the famous qur'ānic scholar al-Suyūṭ̂̄ (d. 1505), was historically established after the hijrah.

2. Some interpretations were attributed to the Companions of the Prophet whose explanations are associated with the Medinan period, whereas the content of the verse belonged to Meccan era. To solve the problem, the later 'ulamā' had to assume that the hukm existed before the text. The qur'anic verse 33 of the Meccan chapter 41 reads: "Who is better in speech than one who calls [men] to Allah, works righteousness, and says "I am of those who bow in Islam". It was quoted from ' $\bar{A}$ 'ishah (one of the wives of the Prophet, d. 678) that the verse was revealed for the muezzin (announcer of the hour of prayer); whereas history tells us adhān (the call for prayer) was established in the early Medinan period. ${ }^{50}$

3. Confusing the sequence of verses with the occasion of revelation resulted in different readings of a verse and in gainsay assumptions: firstly that the text was revealed before the occasion arose, and secondly that the text preceded its suitability and necessity to be a legal norm. An example is verse 45 of chapter 54: "Soon will their multitude be put to flight, and they will show their backs." Al-Suyūṭ̂ quoted the second caliph 'Umar stating that he had heard the Prophet reciting this verse during the Battle of Badr when the army of Quraysh was defeated. Yet the sequence of verses suggests a similarity between the ancient Egyptian Pharaohs and Meccan pagans. Another meaning can be understood by reading 'between the lines' in light of the future tense used in the verse, in that it applies to the Resurrection Day. Abū Zayd concludes that different readings of a text result from the reader's standpoint, and that the evolution of one's knowledge opens the way for a new understanding of the text. ${ }^{51}$

In the quest for finding a new meaning or function for legal principles, Abū Zayd, in Mafhüm al-nașs, draws on a number of methodological topics from ușūl al-fiqh such as the 'general and its particularisation', 'occasions of revelation', 'abrogation', 'implication and divergent meaning' and 'absolute and qualified'. For instance, he evaluates abrogation as the main proof for a dialectical relationship 
exists between the revelation and external realities, and says that its function is to adapt changes and to advance law giving. ${ }^{52} \mathrm{He}$ considers both the generalisation and particularisation of the qur'ānic verses as a means to maintain the unity of the law and to fully understand both the literal expressions and the occasions in which the law was given..$^{53}$ Abu Zayd finally concludes his arguments in the Mafhüm al-naș with a mystical explanation for the relationship of "real to metaphor", as a relationship of change with transformation. ${ }^{54}$

To pave the way for exploring alternative concepts for the religious texts, $A b \bar{u}$ Zayd tries to refute certain Islamic legal interpretations such as the prevailing attitude that there is no room for ijtija $d$ wherever a text is available. He claims that the statement (manțiq $)$ of the Qur'ān is fixed and permanent, but its conception (mafh $\bar{u}$ ) is changeable and open to variable approaches. To establish this claim, Abū Zayd refers to the history of Muslim rational approaches (especially Mu'tazilite approach) in addition to practical principles of legal methodology such as the priority of consideration of public interest (mașlahah) over the text; preservation of objectives (maqāssid) of the law and suitability (munāsabah) of ratio leges in analogous applications. These principles were mainly proposed by the fourteenthcentury jurist al-Shātịīi and endorsed partly by Ibn Taymiyyah and others. Pursuing different objectives or grounding themselves on variable information, Muslim jurists historically presented varying conceptions out of certain texts. ${ }^{55}$

A legal case in point is a daughter's share of inheritance that principally should screen (hajaba) the right of all second-degree relatives in the absence of other first-degree heirs such as brothers. According to most Sunni schools of law, a daughter is not entitled to inherit more than her determined share (fard), which is half, from her parents' bequest. The rest should be returned to either 'așabah (paternal male residuary) or to the public treasury (bayt al-māl) in the absence of other first-degree heirs. Only the Ja farī school of law clearly gives the right to the daughter to appropriate the second half of the bequest by returning (radd) it to her, regardless of the presence of the 'asabah. The above problem was strongly debated in Egyptian media in the 1980s. Abū Zayd supported those writers who had advised the government to enhance women's rights by adopting the Shi'ite position in the law of inheritance. He argues that the different understanding of the same qur'ānic verses by Shi'ites (and some Hanafîs) points to the fact that there is room for $i j t i h \bar{a} d$ and new understanding of the qur'ānic verses. He draws two spheres for understanding the verses:

1. to find out the meaning ( $m a$ ' $n \bar{a})$, and

2. to delineate the end goal (maghzā) of the law. 
Abū Zayd thinks that the focus of the seventh-century Muslims was to adjust the meaning of the verses according to the existing Arab customs. They sometimes sacrificed the spirit and overall objectives of the Qur'ān for its literal consistency. However, this was not the case for some Sufi-like authors, as it is not the case for our modern understanding of the text. ${ }^{56}$

Abū Zayd claims that today's Muslim juridical understanding of the religious discourse (al-khitâa al-dīn $\bar{\imath}$ ) is often more strict than that of their predecessors. He quotes al-Suyūțī's account of the literal categorisation of the qur'ānic verses as an example of the historical approach to the text of the Qur'ān. In his al-Itqān, al-Suyūṭi plainly claims that all legal verses of the Qur'ān are particularised, except 4:23: "Prohibited to you [for marriage] are your mothers". According to Abū Zayd, al-Suyūṭ̂̀ divides the levels of clarity of the qur'ānic verses as follows:

1. A clear verse is the one which does not bear two meanings, and this is a nașs (or the text).

2. Each verse bears two meanings but one is preferable, and that is the $z \bar{a} h i r$ (apparent) one.

3. Should both meanings bear equal weight then the verse is mujmal (generalised).

4. If both meanings are not equal, but the stronger ( $a q w \bar{a})$ does not fit into the overall apparent meaning closely, rather a remote meaning is preferable; and that is called mu'awwal (allegorically interpreted). ${ }^{57}$

5. Abū Zayd concludes that the concept of nașs according to al-Suyūṭ̂̄ and most traditional authors meant nothing but 'clear verse', whereas naș appears often as a 'fixed and sacred verse' in the writings of the later, and especially present, juridical authors, which leaves practically no room for a rational reflection by the human mind..$^{58}$

In 2006, Abū Zayd published an analytic history of reformation of Islamic thought in which he examines various phases of reform that occurred after the encounter of Muslims with the West. He concludes his work with reference to the setback of Iranian intellectuals in the 2005 presidential election. He blames the defeat on the advanced level of an intellectual debate that currently touches on so many issues previously considered taboo. He then plainly identifies this intellectual debate with hermeneutics that was discussed by people like Soroush and Shabestari. Abū Zayd describes the discussion as more than rethinking the Qur'ān, rather it was “[...] humanizing the Qur'ān by formulating a liberal theology". ${ }^{59}$ Here, we see Abū Zayd who was exiled for his rethinking of the Qur'ān methodology, is now concerned about Iranian 'advanced rethinking' that can simply go beyond the traditional frame.

Abū Zayd's works on reading and rethinking Islamic texts have produced a plausible criticism of some traditional approaches to the $\operatorname{sharī}^{-} a h$. This criticism 
proposes a drastic change in both the traditional application and function so as to be able to incorporate timely considerations. In comparison with rational approaches of the past such as the maqāsid theory of al-Shātibī, it does not, however, provide enough of a religious basis to legitimise or to compromise the application of the new approach within the well-founded structure of the sharī'ah. Abū Zayd's writings, nevertheless, influenced some Muslim milieus in North Africa and Indonesia. One may draw parallels between his writings and some new legal proposals for reform in the civil law of the Maghreb (Morocco, Algeria and Tunisia). This proposal reads: "[...] the idea of an immutable and sacred 'Muslim law' is the fruit of a doctrinal development, and a dominant version of history that presents it as a compact and definitive whole". ${ }^{60}$

\section{Concluding Remarks and Recommendations}

Modern approaches to the sharì 'ah propose certain reforms to legal thought either from within, or by borrowing methods beyond the conventional scope such as empiricism and hermeneutics. The clearest proposal for reform from within is offered by Kamali who, like Abū Sulaymān, considers the duality between the 'ulamā' and government since the Umayyad period as the main stumbling block for the advancement of the legal system among Muslims. Kamali suggests that statutory law and governmental ordinances should either take the place of $i j m \bar{a}$ ' and $i j t i h \bar{a} d$, or be incorporated within them. We have seen how two important notions of ijma and shürā have historically exhausted their traditional importance due to the lack of interest by Muslim scholars over time. In Islam, public participation is encouraged in both performing rituals and fulfilling social duties. The latter, nevertheless, has not received so much attention of the 'ulamā' as the former did. As a result, the rules of congregational prayers, for example, are far more elaborate than the principles of $s h \bar{u} r \bar{a}$ that should shape the consultative part of Islamic government. As a result, the Qur'ān, the traditions of the Prophet, and the practices of the early Companions still remain the best sources of inspiration for the theory of public participation in today's Muslim societies. Kamali's suggestion, therefore, offers a new outlook for reviving the forgotten sphere of Islamic public law.

The application of hermeneutics to the reading of legal texts links the criticism of legal methodology with the promise of fresh understandings of the shari ${ }^{\prime} a h$. On the criticism of the present methodology, Abū Zayd believes the conventional literary interpretations (mabhath al-alfāz) are not flexible enough to capture the variety of contextual meanings of a given text. More importantly, the traditional conception of usül al-fiqh ignores the fact that the development of one's knowledge opens the way for a new understanding of the text. New ways of reading the shari 'ah have opened new gates for understanding and updating Islamic law, as Muslims pave 
new ground for applying other relevant disciplines in their quest for fresh readings of the texts, although they can hardly propose a theory for their application.

All the above-mentioned criticism and analysis persuades us that $u s \underline{u} l$ al-fiqh still offers the most important conduit for approaching the sharī'ah. The infiltration of interdisciplinary skills into legal methodology has neither affected its character nor its status. The most serious criticism is addressed to the literary structure of legal texts that appear meta-historical and self-existing (wāqi ' $\bar{l}$ wa nafs al-amrî̀), and thus not open for direct timely adjustments. By offering alternative approaches, such as consideration of maqāsid, the inclusion of empirical deductions and the reevaluation of the sources of the law, some contemporary authors make fresh attempts to align legal methodology with the requirements of time. However, it remains up to modern linguistics and hermeneutics to conform rational concepts to the revealed sources and to propose independent readings side by side with conventional ones.

In closing, we would like to recommend the following:

- The legal theory of Islamic law (ușūl al-fiqh) in its revised structure, as attempted in the works of Mohammad Hashim Kamali, merits attention for integration into the working modalities of Muslim legislative assemblies and parliaments.

- Ijtihād today is a collective endeavour to be exercised by a council of scholars that should include experts not only of Islamic jurisprudence but also of other fields and disciplines. Ijtihād today must also be guided by the higher goals and purposes (maqūssid) of the sharī'ah.

- A textualist approach to the understanding of sharī $a h$ which has characterised the history of Islamic scholarship needs to be moderated by a more empirical approach, as suggested in the works of 'Abd al-Hamīd Abū Sulaymān and Ṭāhā Jābir al- 'Alwānī.

\section{Notes}

1. Mohammad Hashim Kamali, Principles of Islamic Jurisprudence (Cambridge: Islamic Texts Society, 2003), 1-2.

2. Ibid., 9.

3. Ibid., 117-86.

4. Ibid., 187.

5. Ibid .

6. Ibid., 225.

7. Ibid., 312.

8. Ibid., 494-7.

9. Muḥammad b. Idrīs al-Shāfi '̄e al-Risālah, ed. Aḥmad Shākir (Cairo: Dār al-Turāth, 1979), 472.

10. Mohammad Hashim Kamali, Sharī'ah: An Introduction (Oxford: Oneworld, 2008), 221.

11. Mohammad Hashim Kamali, Issues in the Legal Theory of Ușūl and Prospects for Reform (Kuala Lumpur: International Islamic University Malaysia, 2002), 12-25. 
12. Kamali, Principles, 500-12.

13. Ibid., 509, quoting Jamāl al-Dīn 'Ațiyyah, Al-Nazariyyah al- 'Ammmah li 'l-Sharfah (Cairo: Maṭba ah al-Madīnah, 1407 AH [1988 CE]), $189 \mathrm{ff}$.

14. Kamali, Principles, 518.

15. Ibid., 517.

16. 'Abd al-Ḥamīd Abū Sulaymān, Crisis in the Muslim Mind, trans. Yusuf Talal Delorenzo (Herndon VA: International Institute of Islamic Thought, 1997), 4 and 18.

17. Ibid., 37-8 and Abū Sulaymān, Towards an Islamic Theory of International Relations: New Directions for Methodology and Thought (Herndon VA: International Institute of Islamic Thought, 1994), 65. Here, Abū Sulaymān includes 'urf (custom), 'aql (reason) among the sources as well.

18. Abū Sulaymān, Towards, 117; Crisis, 53.

19. Abū Sulaymān, Towards, 66-9.

20. Abū Sulaymān, Crisis, 49

21. Hibat-Allāh Ibn Salāmah Ibn Nașr al-Muqirrī, al-Nāsikh wa 'l-mansūkh min kitāb Allāh (Beirut: al-Maktabah al-Islāmiyyah, 1984), 98.

22. Abū Sulaymān, Towards, 83-4.

23. Ibid., 78-9.

24. Ibid., 77.

25. Abū Sulaymān, Crisis, 57.

26. Abū Sulaymān, Towards, 85-7.

27. Ibid., $74-5$.

28. Ibid., 25 and 87.

29. Abū Sulaymān, Crisis, 26.

30. Țāhā Jābir al- 'Alwānī, "The Crisis in Fiqh and the Methodology of Ijtihād", American Journal of Islamic Social Sciences 8, no. 2 (September 1991), 317.

31. Ibid., 321 (based on 'Abd al-Malik al-Juwaynī, al-Burhān (Qatar: Mațba 'ah al-Dawhah al-Hadīthah, $1399 \mathrm{AH}$ [1979 CE]), 2:1146. Al-'Alwānī does not take into consideration that the very idea of 'closure of the door of ijtihād' was challenged by some contemporary authors such as Wael Hallaq in his article "Was the Gate of Ijtihād Closed?", International Journal of Middle East Studies 16 (Spring 1984), 3-41.

32. Al- 'Alwān̄i, "The Crisis", 321.

33. Ibid.

34. Țāhā Jābir al- 'Alwānī, Source Methodology in Islamic Jurisprudence (London and Washington DC: IIIT, 2003), xi.

35. Ibid., 68-70.

36. Ṭāhā Jābir al- 'Alwānī, "Ijtihād and Taqlīd", American Journal of Islamic Social Sciences 8, no. 1 (March 1991), 130-2.

37. Ibid., 134.

38. Ibid., 138-40.

39. Țāhā Jābir al- 'Alwān̄̄, Maqāṣid al-sharī' ah (Beirut: Dār al-Hādī, 2001), 63-6.

40. Ibid., 78-82.

41. Ibid., 123-9.

42. Ibid., 67-9.

43. Țāhā Jābir al- 'Alwānī, The Ethics of Disagreement in Islam (Herndon VA: International Institute of Islamic Thought, 1997), 131.

44. See Van A. Harver, "Hermeneutics", The Encyclopedia of Religion, 16 vols (New York: Macmillan, 1987), 6:279-87.

45. See Nașr Ḥāmid Abū Zayd, Ishkālāt al-qirā'ah wa 'l- 'āliyyāt al-ta 'wūl (Cairo: al-Markaz al-Thaqāfī al- Arabī, n.d.), 13-49 This book is a collection of seven articles published in Egyptian journals between 1981 and 1988.

46. Ibid., 15.

47. Abū Zayd, Mafhūm al-naș̣̣ (Cairo: al-Markaz al-Thaqāfī al- 'Arabīi, 1987), 9-13.

ICR 1.3 Produced and distributed by Pluto Journals ICR.plutojournals.org 
48. Abū Zayd, Naqd al-khițāb al-dīn̄̄ (Cairo: Sīnā li '1-Nashr, 1992), 74.

49. Abū Zayd, Mafhūm al-nașș, 89.

50. Ibid., 93-4.

51. Ibid., 89-95.

52. Ibid., 117, 120.

53. Ibid., 195.

54. Ibid., 245-97.

55. Abū Zayd, Naqd al-khițāb al-dīnī, 82-6, also see 59.

56. Ibid., 85-6, 105 and 219-20.

57. Jalāl al-Dīn al-Suyūțī, al-Itqān fì 'ulūm al-Qur'ān (Cairo: Mușțafā Albānī al-Halabī, 1951), 2:16; see also Abū Zayd, Naqd al-khițāb al-dīnī, 92.

58. Abū Zayd, Naqd al-khițāb al-dīnī, 91-4.

59. Nașr Hāmid Abū Zayd, Reformation of Islamic Thought: A Critical Historical Analysis (Amsterdam: Amsterdam University Press, 2006), 78-9.

60. Collectif 95 Maghreb Egalité, Dalil pour l'égalité dans la famille au Maghreb (Rabat: Collectif 95, 2003), 14. 